\title{
Creation and Validation of an Educational Video about the Importance of the Preanesthetic Consultation
}

\author{
Aderval de Melo Carvalho Filho, Eliane Monteiro Cabral Warren, \\ Isabella Costa Figueiredo Medeiros, Erika Patrícia Rodrigues de Melo, \\ Rozangela Maria de Almeida Fernandes Wyszomirska, Almira Alves dos Santos \\ Universidade Estadual de Ciências da Saúde de Alagoas (UNCISAL), Maceió, Brazil \\ Email: almira_alves@yahoo.com.br
}

How to cite this paper: de Melo Carvalho Filho, A., Warren, E. M. C., Medeiros, I. C. F., de Melo, E. P. R., de Almeida Fernandes Wyszomirska, R. M., \& dos Santos, A. A. (2020). Creation and Validation of an Educational Video about the Importance of the Preanesthetic Consultation. Creative Education, 11, 834-844.

https://doi.org/10.4236/ce.2020.115060

Received: May 1, 2020

Accepted: May 25, 2020

Published: May 28, 2020

Copyright $\odot 2020$ by author(s) and Scientific Research Publishing Inc. This work is licensed under the Creative Commons Attribution International License (CC BY 4.0).

http://creativecommons.org/licenses/by/4.0/

\begin{abstract}
Introduction: The pre-anesthetic consultation (PAC) is considered a fundamental step in the perioperative phase, and it is a moment of communication between the anesthesiologist and the patient, where the patient can be informed and clarified, characterizing this a communicative and therapeutic process. However, its benefits are still generally unknown. Educational videos are surfacing as fast-access media that can reach a wide audience. Some studies have highlighted the benefits of using educational videos about PAC. In this context the current study provides an experience report about the process of creation and validation of an educational video about PAC. Methods: In order to choose an educational product, the technical aspect, as well as the cognitive, multisensory stimuli and personality structure of individuals must be observed. This educational video was made based on the CTM3 method consisting of the following stages: Educational product Conception (C); Theoretical framework (T); and Methodological framework (M3), this last one is based on 3 theories: Transactional Analysis, Multisensory Exploration, and Neurolinguistics. Results and Discussion: The creation and validation of this educational video comprised seven stages. The video length was approximately 2 minutes 24 seconds, and it was projected in 10 scenes. Finally, the video was submitted to a validation process by an ad hoc committee. The advantages of educational resources, particularly videos for health education, are well defined being an increasingly used resource especially in interventions. The use of the CTM3 Method was fundamental because its methodology involves particularly the cognitive and sensory aspects and the specificities of each person. Conclusion: The use of CPA educational videos, due to their great capacity to attract attention of viewers, can help to inform the patient. Based on pre-
\end{abstract}


vious studies about the use of videos, as well as cognitive and sensory aspects, it is also concluded that this educational video is relevant and has the potential to promote $\mathrm{CPA}$ information to its target audience.

\section{Keywords}

Health Education, Edu-Communication, Anesthesia and Analgesia, Audiovisual Resources, Sensory Functions

\section{Introduction}

The pre-anesthetic consultation (CPA) is a fundamental step for the preoperative preparation of the patient (Brazil, 2017), and can be defined as a process that precedes the stage of administration of anesthesia for surgical or diagnostic procedures. The gold standard of the CPA assumes that it takes place in an office, whenever possible before the patient's hospitalization (Mathias, 2016). The general public is unaware of the benefits of CPA. An interesting and effective way of transmitting this information is through health education which, according to Santos, Alves, Warren, \& Wyszomirska (2019), is a strategy used through interventions with the objective of facilitating learning, changing habits and bringing benefits to the population object of the intervention. For those who educate, a great challenge is to awaken reasons for learning, with the aim of making topics more interesting, being able to work them through technological resources, so that knowledge can be disseminated more efficiently (Moreira, 2006; Gómez \& Pérez, 2013). One of the widely used resources consists of educational products, which are defined as facilitators of learning on any topic (Ruiz, Motta, Bruno, Demonte, \& Tufró, 2014), must be easily accessible, available on the internet, through institutional repositories and open access platforms (Nielzer, Fabri, Frasson, \& Pilatti, 2015). Among these resources, videos stand out as a means of easy communication and quick access, reaching a wide and varied audience, disseminating information in a playful and attractive way, causing a positive impact on the transmission of information and content, exploring the view and the visualization of people, colors, scenarios, spatial relationships, among other associations (Moran, 2002; Williams, 1988; Coutinho, 2008).

Studies reinforce the importance of educational videos and their impact on the populations studied, especially in the surgical area and in anesthesiology. Another important step is the process of validating a product, as to this process it is attributed the veracity that what was proposed and attested by those who evaluated declares the material's capacity to produce what was proposed; confirms that the content and form of technical production work according to its objective (Ruiz et al., 2014). The validation of educational products is recommended by Fondo de las Naciones Unidas para la Infancia (UNICEF, 2003) and CAPES in their teaching document (Brazil, 2019). The term "validate" means to 
verify and in these cases, whether the educational material is suitable for the target audience, whether it meets the expectations of form (Ziemendorff \& Krause, 2003). According to Leite (2018), it is important to validate these products, through reflections on issues relevant to each specific format. Lastly, Latini, Oliveira, Anjos, \& Carvalho (2011) emphasize the relevance of creating categories for the analysis of educational products and reiterate the need to verify their contribution to the improvement of teaching practice, promoting the articulation between theory and practice and social insertion. Oliveira, Santos, \& Santos (2002: p. 127), evaluating the effectiveness of three educational games focused on oral hygiene, concluded that "There was an effectiveness in the application of educational games as a means to help change oral hygiene habits in children".

This experience report refers to the process of building and validating an educational video, the main purpose of which is to alert, clarify and guide the interested public on the importance and advantages of CPA, based on the current legislation on the anesthetic act, in addition to the scientific literature (Brazil, 2017). This theme was chosen due to the evidence that shows the importance of pre-anesthetic consultation (for better clarification and reduction of the anxiety level of surgical patients) as well as the relevance of educational videos for this purpose.

\section{Methods}

The experience report is a tool that presents a reflection on an action or a set of actions that address a situation experienced in the professional sphere of interest to the scientific community.

\subsection{Conception and Construction of the Educational Product}

The conception of the product is the initial moment, where the theme, the type and what elements will compose this product are established. It is the moment of creativity, it is when we ask ourselves what resource we will produce-A video, a board game, a booklet, an e-book or blog? Online or printed? - In order to answer these questions, it is necessary to know the target audience and the characteristics of such audience, therefore, this prior knowledge is fundamental for good planning.

The construction of the video was carried out during the Educational Resources discipline of the master's degree program in Health Teaching and Technology, at the State University of Health Sciences of Alagoas-UNCISAL. Due to the main author being a student of the program and a physician anesthesiologist perceiving in his daily practice the difficulty felt by patients in the face of pre-anesthetic consultation, as well as the relevance of the theme, hence the option for an elaboration of a video as an educational product. The structuring and preparation of the video occurred between the months of June and July 2019. The software Adobe Première Procc 2018 and Photoshop cc 2018 were used, with the technique of 2D Animation. The video was made in 16:9 aspect, and the 
sound used was of 2.0 stereo quality. It is available on the EDUCAPES Platform through the link http://educapes.capes.gov.br/handle/capes/560063, which is freely accessible, confirming the indication of Nielzer et al. (2015). Its construction was based on the CTM3 method developed by Santos et al. (2019), which recommends the execution of three stages, namely: (C) Conception of the educational product; (T) Theoretical framework on the topic; and (M3) methodological framework, based on three theories: Transactional Analysis, Multisensory Exploration, and Neurolinguistic Programming (Muller, 2016).

\subsection{Theoretical Framework}

The theoretical framework is located in the main electronic databases: Latin American and Caribbean Literature in Health Sciences (LILACS) and International Literature in Health Sciences (MEDLINE), Red Portal of Scientific Journals of Latin America and the Caribbean, España y Portugal (Redalyc), Scientific Open Access Scientific Repository of Portugal (RCAAP), Scientific Electronic Library Online (SciELO) and Google Scholar. In this work, it was included studies on the topic of pre-anesthetic consultation and its importance, as well as on educational resources and the process of construction and validation of educational resources.

\subsection{Methodological Framework}

The methodological framework embodies the method used in making the product and was based on the three theories, namely: Transactional analysis with the insertion of elements with the potential to evoke in the individuals the three states of Ego (Father, Adult and Child). Multi-sensoriality, with the insertion of elements that can awaken the five senses (sight, smell, taste, hearing and synesthetic) in the target audience and the neurolinguistic programming inserting anchors, defined here as anything that gives access to an emotional state, or to a memory (O'Connor \& Seymour, 1995). It is worth mentioning that all planning of the methodological framework focused on the insertion of all the elements mentioned above, exploring the target audience with the three states of ego, the five senses and the anchors, this is due to the difficulty in accurately identifying which of these elements will be available to each individual the moment he has access to the product, therefore, it is essential that the approach through the elements is multiple and assertive.

\subsection{Product Validation}

For this work, technical validation was used, following a script:

1) Publication of public notice for product registration;

2) Three to five ad hoc evaluators are invited to the validation session, with-at least-a master's degree or preferably doctors in the area of Communication, Education and Health, with an emphasis on evaluators with expertise in Education and Communication. 
3) Oral presentation of the product, followed by the evaluators' question, filling in the Evaluation Instrument and finally, issuing a conclusive assessment report: Validation, Validation after corrections and Non-Validation.

\section{Results and Discussion}

This work consists of an experience report of the construction and validation of an educational video whose main purpose is to alert, clarify and guide the general public about the importance and advantages of CPA. According to Santos, Fernandes, \& Oliveira (2012), the main benefit of the reception performed by the anesthesiologist at CPA is the opportunity to clarify, clarify doubts, being an important communication process. It is also the moment when the doctor has the opportunity to inform the patient about the possible anesthetic techniques options (according to the proposed procedure), reporting in detail the sequence of events that will happen, including the steps since the patient's entry into the hospital until discharge from Post-Anesthetic Recovery (PACU) (Mathias, 2016). A poorly performed preoperative evaluation, according to Kluger, Tham, Coleman, Runciman, \& Bullock (2000), is responsible for $11 \%$ of serious intraoperative incidents, and half of these could be avoided, with efficient doctor-patient communication at CPA.

Regarding the use of videos on CPA, Lin et al. (2016), studying 100 patients with scheduled surgeries and aiming to investigate the effect of a video with information about anesthesia, reported a decrease in the state of anxiety in the group that watched the video, in relation to the group that only obtained verbal instructions. Another study, in order to analyze the effect of an informative video on anxiety and patients undergoing spinal anesthesia, in which 198 patients participated, concluded that the provision of video information during CPA caused relief of anxiety and increased satisfaction (Cakmak et al., 2018). A third study, conducted in Taiwan, also with the objective of investigating the effects of a video with anesthetic information, found that there was a significant reduction in anxiety levels and increased satisfaction in the group that watched the video, compared to the group that received guidance statements about anesthesia (Lin et al., 2016). These studies reinforce the importance of educational videos when analyzing their impact on the studied populations, but they do not report on what the process of making these videos was based, or on what theoretical framework they were based upon.

\subsection{Contextualizing the Conception of the Video}

The Educational Resources discipline is taught in the Professional Master's Degree Program in Health Teaching and Technology at the State University of Health Sciences of Alagoas-UNCISAL, in Brazil, providing students with the theoretical basis for product development, with the evaluation activity being the development of an educational product, with potential for application on the practice of the health professional. After researching the theoretical framework and the 
methodological framework, a decision was made to produce a video with the elaboration of scenes, described in order to explore the states of ego, senses and the insertion of anchors aiming to enhance learning. At a later time, the video was edited, using the help of a technical professional and computer programs.

\subsection{Construction of the Video}

A communication/educational material must combine knowledge and technology, in order to disseminate/transmit knowledge, exchange of information and training to the target audience. Each type of material has its specificities and potentials and must be carefully worked on, as the target audience, based on the information provided, can acquire knowledge and use this information, replicating them.

The video was conceived from discussion meetings of the authors of the work, as well as from the discussion of the topic with some colleagues who are anesthesiologists and finally reading articles on the use of educational videos for the public According to Moran (2002), videos are easy to communicate and have quick access, reaching a wide and varied audience. As compared with Muller (2016), this resource can explore multi-sensoriality, converting it into information that reaches the processing center-brain-in the form of sensory stimuli. Next, a script was elaborated, based on the most relevant information about $\mathrm{CPA}$, observing the care with a simple and clear language, aiming to transmit the content to the target audience, literate or not. The script consisted of topics, with the elaboration of short phrases, narrated in the active voice. The visual resources were chosen based on keywords that best synthesized the topics. According to Fiorentini \& Carneiro (2002), the script must be written in a language that expresses not only speech, but also images and body expressions. The next step was the organization of the scenes, respecting each topic and adding the appropriate audiovisual resources for each shot. Care was taken to harmonize the images and sounds with the information transmitted in each scene. Finally, elements that address the individual's cognitive aspects were inserted, for greater effectiveness in communication and aiming at access to a greater number of individuals (Santos et al., 2019).

The images used in the video are in the public domain, the voice belongs to the main author and for this reason, an authorization term for the dissemination of the narrated sounds was signed. The video has an approximate duration of 2 minutes and 24 seconds consisting of 10 scenes:

1) First scene: presentation about the $\mathrm{CPA}$, drawing public attention to its importance. This way it evokes the Adult ego State in which there is objective reasoning, the analysis of reality. The scene also works with visual and sound stimuli.

2) Second scene: the objective is to emphasize the fact that CPA is usually the patient's first contact with the anesthesiologist. In this scene there is the evocation of the Parent ego state which has the purpose of educating, protecting. When conveying a sense of embracement, it also evokes the Child ego state. Finally, it also works with visual and sound stimuli. 
3) Third scene: alerts of the importance of the patient providing all information about his background, illnesses and drug allergies, thus evoking the Adult ego state. It also works with visual and sound stimuli.

4) Fourth scene: reinforces the importance of the patient in providing information and solving all his doubts with the professional, such as the proper performance of the preoperative fasting, types of anesthesia available, among others. When illustrating the image of a meal, this scene evokes gustatory and olfactory stimuli, as well as the Child and Adult ego states.

5) Fifth scene: more CPA benefits are reported, thus evoking the Child and Parent egos. Like the previous scenes, it transmits visual and sound stimuli.

6) Sixth scene: when reporting on the reduction of anxiety and fear, it evokes the Child ego, responsible for emotions, in addition to working with visual and sound stimuli. When showing a healthcare professional touching his patient's hand, he evokes the tactile sense.

7) Seventh scene: brings information present in the Resolution of the Federal Council of Medicine of Brazil (Brazil, 2017), with the intention of evoking the Adult ego, that of logical reasoning.

8) Eighth scene: it is one of the most important, as it emphasizes that CPA can bring greater satisfaction to the patient, due to the fact of promoting a recovery of higher quality; evokes the Child ego and the Parent ego, regarding care. It brings sound, visual and tactile stimuli, showing an image of father and son holding hands.

9) Ninth scene: addresses the importance and advantages of CPA for the obstetric patient, thus evoking the Parent ego and the Adult ego. It also brings sound and visual stimuli.

10) Tenth scene: evokes the Parent and Adult ego states, when guiding the patient to require pre-anesthetic consultation.

There was an anchor inserted in all scenes as the image of a stethoscope and clipboard in order to reinforce the message. Several studies report that surgical patients very often have preoperative anxiety, probably started at the time of surgery planning (Krupat, Fancey, \& Cleary, 2000; Macario, Weinger, Truong, \& Lee, 1999). Other studies conclude that there is also an increase in the degree of satisfaction and understanding of patients, in addition to a reduction in anxiety, when they are informed through educational videos in comparison to the transmission of information only verbal or written (Done \& Lee, 1998; Bondy, Sims, Schroeder, Offord, \& Narr, 1999; Lee, Chui, \& Gin, 2003; Lemos, Lemos-Netoa, Barrucand, Verçosa, \& Tibirica, 2019).

The information transmitted through videos brings up attention and memorization, hence the reason this resource has been increasingly utilized as informational support in the health area, especially in intervention actions, thus having great pedagogical power (Moraes, 2008). Still according to Moraes (2008), videos have the power to intervene, being able to participate in disease prevention and health promotion actions by changing people's behaviors. 
Videos still play a very relevant role in the teaching process, even after the emergence of new technological and media resources, such as social media and the internet. According to Moran (2002), video can also bring knowledge through the senses, through what is seen and felt, in addition to sound effects, which help in fixing the information contained in the videos themselves.

\subsection{Video Validation}

After editing, the video was entered in the Educational Products Validation Session, organized by the Professional Master's Degree Program in Health Teaching and Technology at the State University of Health Sciences of Alagoas-UNCISAL, held on November 12, 2019, following the script recommended by the Institution and already described in methods. The opinion of the ad hoc evaluators was in favor of validation.

The video was deposited on the eduCAPES open educational objects portal, on November 25, 2019 and can be accessed through the link:

http://educapes.capes.gov.br/handle/capes/560063.

\section{Conclusion}

The use of the CTM3 Method was essential for the elaboration of the video, as its methodology considers, particularly, the cognitive and sensory aspects, as well as the specificities of each individual. Some difficulties were encountered in the making of this video including how to explore all the senses and how to adapt them maintaining the original requirement which was to make it interesting and didactic, however, without distancing itself from the initial concept of simplicity in an educational video. The insertion of anchors and working with the ego states in the scenes also requires skill, something that is greatly facilitated with the use of the above-mentioned method. It is a process which requires planning, furthermore it is important to highlight that the video may not be lengthy in order not to cause disinterest to the audience.

Finally, after reporting its construction and validation steps, in addition to reporting previous experiences on the use of video in anesthesiology, we can conclude that the video has enormous potential to reach its target audience, bringing numerous benefits, among them, the reduction of the target audience's anxiety, improved communication and empathy between doctors anesthesiologist and his or her patient. In addition, it can also be used as a tool for the permanent education of health teams, causing an indirect impact on better management and preparation of the preoperative period, contributing to reduce hospital and health care costs by reducing the rate suspension of surgeries, as well as reducing the request for unnecessary preoperative exams.

The video is freely reproducible, being an open educational resource, which can be made available on platforms and media, for the general population, health teams, as well as being shown in the waiting rooms of the offices and clinics. 


\section{Funding}

The publication of this article had the financial support of the State University of Health Sciences of Alagoas-UNCISAL.

\section{Conflicts of Interest}

The authors declare no conflicts of interest regarding the publication of this paper.

\section{References}

Bondy, L. R., Sims, N., Schroeder, D. R., Offord, K. P., \& Narr, B. J. (1999). The Effect of Anesthetic Patient Education on Preoperative Patient Anxiety. Regional Anesthesia \& Pain Medicine, 24, 158-164. https://doi.org/10.1097/00115550-199924020-00011

Brazil (2017). Resolução 2.174, de 14 de dezembro de 2017. Dispõe sobre a prática do ato anestésico e revoga a Resolução CFM n 1.802/2006. https://www.sbahq.org/wp-content/uploads/2018/03/RESOLUC\%CC\%A7A\%CC\%83O -2_174-de-14-de-dezembro-de-2017-Dia\%CC\%81rio-Oficial-da-Unia\%CC\%83o-Impr ensa-Nacional.pdf

Brazil Ministério da Educação (2019). Documento de Área-Área 46-Ensino. http://capes.gov.br/images/Documento_de_\%C3\%A1rea_2019/ENSINO.pdf

Cakmak, M., Kose, I., Zinzircioglu, C., Karaman, Y., Tekgul, Z. T., \& Pektas, S. (2018). Effect of Video-Based Education on Anxiety and Satisfaction of Patients Undergoing Spinal Anestesia. Revista Brasileira de Anestesiologia, 68, 274-279. https://doi.org/10.1016/j.bjane.2018.01.004

Coutinho, C. P. (2008). A influência das teorias cognitivas na investigação em Tecnologia Educativa: Pressupostos teóricos e metodológicos, expectativas e resultados. Revista Portuguesa de Educação, 21, 101-127. https://doi.org/10.21814/rpe.13921

Done, M. L., \& Lee, A. (1998). The Use of a Video to Convey Preanesthetic Information to Patients Undergoing Ambulatory Surgery. Anesthesia \& Analgesia, 87, 531-536. https://doi.org/10.1213/00000539-199809000-00005

Fiorentini, L. M. R., \& Carneiro, V. L. Q. (2002). TV na escola e os desafios de hoje: Curso de extensão para professores do ensino fundamental e médio da rede pública (2nd ed.). Brasília: Editora Universidade de Brasília.

Fondo de las Naciones Unidas para la Infancia (UNICEF) (2003). Guia metodologica y video de validacion de materiales. https://www.unicef.org/peru/media/2436/file/Video\%20Validación\%20de\%20Material es.pdf

Gómez, I. D. C., \& Pérez, R. C. (2013). Del vídeo educativo a objetos de aprendizaje multimedia interactivos: Un entorno de aprendizaje colaborativo basado en redes sociales. Tendencias Pedagógicas, 22, 59-72.

Kluger, M. T., Tham, E. J., Coleman, N. A., Runciman, W. B., \& Bullock, M. F. (2000). Inadequate Preoperative Evaluation and Preparation: A Review of 197 Reports from the Australian Incident Monitoring Study. Anaesthesia, 55, 1173-1178. https://doi.org/10.1046/j.1365-2044.2000.01725.x

Krupat, E., Fancey, M., \& Cleary, P. D. (2000). Information and Its Impact on Satisfaction among Surgical Patients. Social Science \& Medicine, 51, 1817-1825.

https://doi.org/10.1016/S0277-9536(00)00113-1 
Latini, R. M., Oliveira, L. R. de, Anjos, M. B. dos, \& Carvalho, R. H. de S. B. F de. (2011). Análise dos produtos de um Mestrado profissional da área de Ensino de Ciências e Matemática. Ensino, Saúde e Ambiente, 4, 45-57.

https://periodicos.uff.br/ensinosaudeambiente_backup/article/viewFile/14589/9193 https://doi.org/10.22409/resa2011.v4i2.a21091

Lee, A., Chui, P. T., \& Gin, T. (2003). Educating Patients about Anesthesia: A Systematic Review of Randomized Controlled Trials of Media-Based Interventions. Anesthesia \& Analgesia, 96, 1424-1431. https://doi.org/10.1213/01.ANE.0000055806.93400.93

Leite, P. S. C. (2018). Produtos Educacionais em Mestrados Profissionais na Área de Ensino: Uma proposta de avaliação coletiva de materiais educativos. Atas-Investigação Qualitativa em Educação, 1, 330-339.

Lemos, M. F., Lemos-Netoa, S. V., Barrucand, L., Verçosa, N., \& Tibirica, E. (2019). A informação no pré-operatório reduz a ansiedade pré-operatória em pacientes com câncer submetidos à cirurgia: Utilidade do Inventário Beck de Ansiedade. Revista Brasileira de Anestesiologia, 69, 1-6. https://doi.org/10.1016/j.bjan.2018.07.003

Lin, S. Y., Huang, H. A., Lin, S. C., Huang, Y. T., Wang, K. Y., \& Shi, H. Y. (2016). The Effect of an Anaesthetic Patient Information Video on Perioperative Anxiety: A Randomised Study. European Journal of Anaesthesiology, 33, 134-139. https://doi.org/10.1097/EJA.0000000000000307

Macario, A., Weinger, M., Truong, P., \& Lee, M. (1999). Which Clinical Anesthesia Outcomes Are Both Common and Important to Avoid? The Perspective of a Panel of Expert Anesthesiologists. Anesthesia \& Analgesia, 88, 1085-1091. https://doi.org/10.1213/00000539-199905000-00023

Mathias, L. A. S. T. (2016). Avaliação e Preparo pré anestésico. In Sociedade Brasileira de Anestesiologia (Ed.), Bases do ensino de Anestesiologia (pp. 81-95). Rio de Janeiro: SBA.

Moraes, A. F. (2008). A diversidade cultural presente nos vídeos em saúde. Interface (Botucatu), 12, 811-822. https://doi.org/10.1590/S1414-32832008000400011

Moran, J. M. (2002). Desafios da televisão e do vídeo à escola. http://www.eca.usp.br/prof/moran/site/textos/tecnologias_eduacacao/desafio.pdf

Moreira, M. A. (2006). A teoria da aprendizagem significativa e a sua implementação na sala de aula. Brasília: Editora da UNB.

Muller, R. (2016). Neurociência cognitiva e a nossa realidade. http://www.sbneurociencia.com.br/drrobertomuller/artigo1.htm

Nielzer, T. M., Fabri, F., Frasson, A. C., \& Pilatti, L. A. A. (2015). Caracterização dos Produtos Desenvolvidos por um Programa de Mestrado Profissional da Área de Ensino de Ciências e Tecnologia. Revista Brasileira de Ensino de Ciência e Tecnologia, 8, 1-30. https://doi.org/10.3895/rbect.v8n3.2084

O’Connor, J., \& Seymour, J. (1995). Introdução à Programação Neurolinguística: Como entender e influenciar as pessoas. São Paulo: Summus.

Oliveira, T. J. S., Santos, A. A., \& Santos, T. J. S. (2002). Aplicação de jogos educativos-uma avaliação de mudança no hábito de higienização bucal. Odontologia Clínico-Científica, $1,123-128$.

Ruiz, L., Motta, L., Bruno, D., Demonte, F., \& Tufró, L. (2014). Producción de materiales de comunicación y educación popular. Ciudad Autónoma de Buenos Aires: Departamento de Publicaciones de la Facultad de Derecho y Ciencias Sociales de la Universidad de Buenos Aires.

Santos, A. A., Alves, C. F., Warren, E. M. C., \& Wyszomirska, R. M. A. F. (2019). Integrated Model of Course Based on Edu-Communication and Psycho-Communication in Learning. Creative Education, 10, 1080-1090. https://doi.org/10.4236/ce.2019.106081 
Santos, M. F. O., Fernandes, M. G. M., \& Oliveira, H. J. (2012). Acolhimento e Humanização na Visão dos Anestesiologistas. Revista Brasileira de Anestesiologia, 62, 199-213. http://www.scielo.br/pdf/rba/v62n2/v62n2a06.pdf https://doi.org/10.1590/S0034-70942012000200006

Williams, S. (1988). Education and the Information Revolution. In N. Paine (Ed.), Open Learning in Transition (pp. 3-13). London: Kogan Page.

Ziemendorff, S., \& Krause, A. (2003). Guia de validacion de materiales educativos (con enfoque en materiales de educacion sanitaria). La salud de las poblaciones indigenas (pp. 1-85). Chiclayo: Convenio GTZ-OPS. 